\title{
Variations in Aggregate Stability and selected Soil Chemical Properties Under Different Land Use Systems in Ikpe Ikot Nkon, Southeastern, Nigeria
}

\author{
Uzoma Kingsley Chinyere ${ }^{1 *}$ and Onwuka Brown Mang ${ }^{1}$ \\ Department of Soil Science and Meteorology, Michael Okpara University of Agriculture Umudike, Nigeria
}

Submission: August 16, 2018, Published: September 17, 2018

"Corresponding author: Uzoma Kingsley Chinyere, Department of Soil Science and Meteorology, Michael Okpara University of Agriculture Umudike, PMB 7267, Umuahia, Abia State, Nigeria; Tel: 07066129991; Email: kingsolisis@yahoo.com

Abstract

The changes in aggregate stability and selected chemical properties of soils under cassava cultivated land, oil palm plantation and rubber plantation were studied in Ikpe Ikot Nkon, Ini local government area, Akwa Ibom State. Results showed that textural class of cassava cultivated land was sandy loam (SL) where as other land use systems were dominated by sandy clay loam (SCL) and clay loam (CL). Total porosity, saturated hydraulic conductivity and infiltration rate showed an inverse relationship with bulk density. Soils under oil palm plantation were significantly $(\mathrm{p} \leq 0.05)$ more porous than the others. The mean weight diameter was highest in oil palm plantation (OP) and significantly different from cassava cultivated land (CS) which had the lowest. At the micro aggregate level, cassava cultivated land (CS) appeared to be better than others. Values for organic matter in cassava cultivated land were lower than others ranging from 21.70 to $25.90 \mathrm{~g} \mathrm{~kg}^{-1}$ where as others were high ranging from 23.40 to $28.30 \mathrm{~g} \mathrm{~kg}^{-1}$ with oil palm plantation recording the highest. The $\mathrm{pH}$ of the soil ranged from very strongly acidic to moderately acidic. Sand particles positively correlated significantly with CDI and DR in all the soils and negatively with CFI and ASC. This relationship was reversed for clay and OM contents for CDI, DR, CFI and ASC, respectively. There was a positive significant correlation between OM, clay and MWD in soils from oil palm plantation and rubber plantation, $\mathrm{OM}$ was shown to enhance aggregation.

Keywords: Aggregate stability; Land use systems; Micro aggregate stability; Wetting and drying cycles; Soil physical properties

Abbreviations: SL: Sandy Loam; SCL: Sandy Clay Loam; CL: Clay Loam; OP: Oil Palm Plantation; MWD: Mean Weight Diameter; DR: Dispersion Ratio; CFI: Clay Flocculation Index; CDI: Clay Dispersion Index; ASC: Aggregate Silt Clay; RCBD: Randomized Complete Block Design; RP: Rubber Plantation

\section{Introduction}

Soil aggregate stability is an attribute that contributes to sustainable soil quality and soil erosiivity [1]. Soil structural stability is a measure of soil's ability to retain its structure after the application of a mechanical stress or destructive forces [2]. Aggregate stability influences several aspects of soil physical behaviour, especially moisture transmission and erosive effect of rain drops and wind [3]. Aggregate breakdown is important in the soil detachment because it produces finer particles that are splashable by raindrops [2], which can also seal the micro pores. Therefore, soil aggregate stability is considered to be a very important property that determines soil erodibility and crustability [1]. During soil aggregate formation, primary particles are bound into micro aggregates, which are bound into macro aggregates [3]; Organic matter plays a major role on control of aggregate formation, which, in turn, affect the organic matter stabilization and long-term soil aggregate stability [4]. It is also recorded that decomposition of organic matter plays a key role in early stages of aggregate formation following organic matter input to soil $[5,6]$. Land use system involves changes, maintenance, arrangements, activities and inputs people undertake in certain land cover type to produce their major needs (food clothing and shelter) and raw materials for industries [7]. The distribution and supply of nutrients in the soil are affected by modifications in land use systems through directly altering soil properties and by influencing biological activities over a period of time [8].

A study of the aggregate stability and selected soil chemical properties of three land use types in the study area would assist policy makers and land users in agriculture and environment to adopt the best land use systems that would enhance soil quality in terms of aggregate stability as well as proffer excellent methods of sustainably managing the soil to enhance productivity. Therefore, the objective of the study was to investigate the variations in aggregate stability and selected soil chemical properties under cassava cultivated land, oil palm plantation and rubber plantation. 


\section{Materials and Methods}

\section{Study area}

The study was carried out in Ikpe Ikot Nkon in Ini Local Government of Akwa Ibom State, Southeastern, Nigeria. The area is located within latitude latitudes $4032^{\prime} \mathrm{E}$ and $5033^{\prime} \mathrm{N}$ and Longitudes $7 \mathrm{o} 25^{\prime}$ and $8025^{\prime}$ E. It has a total area of $320,45 \mathrm{~mm} 2$ [9]. The location has a mean annual rainfall of $3000 \mathrm{~mm}$ (Nigeria Meteorological Agency, 2015). The rainfall is bimodal, starts in April and ends in October with peaks in June and September [10]. The geology of In Local Government area consist mainly of the coastal plain sand and sandstone east of Nkari, Obotme which stretches to Its and Enyong creek confluence [9]. Within the location, cassava cultivated land, oil palm plantation and rubber plantation were investigated. These sites are within Ikpe Ikot Nkon metropolis.

\section{Soil sampling}

Under each land use system, 3 sampling points were located randomly. Around each of the 3 sampling points within a land use, soil samples were collected at 2 depths $(0-15$ and $15-30 \mathrm{~cm})$ using soil auger. This constituted a total of 6 samples for each land use and a grand total of 18 bulk samples for the 3 land uses. Two core samples were collected, one at $0-15 \mathrm{~cm}$ and the other at $15-30 \mathrm{~cm}$ from each of the 3 sampling points making a total of 6 core samples in each land use. Also, a total of 18 core sample were collected for analysis.

\section{Sample preparation}

The soil samples collected with the soil anger were air-dried and sieved through $2 \mathrm{~mm}$ sieve size. Samples for mean weight diameter (MWD) were only sieved through $4.75 \mathrm{~mm}$ sieve size. The Samples for other chemical analysis were further crushed after sieving with $2 \mathrm{~mm}$ sieve size. The base of the core samples was covered with a cheese cloth and saturated in water for determination of some physical properties.

\section{Laboratory analysis}

The following properties were determined.

Particle size analysis: (Bouyoucos hydrometer method) as outlined by kettler et al. [11].

Bulk density: By the method described by Blake [12].

\section{Porosity}

a. Total porosity: total porosity was determined from bulk density value assuming particle density to be $2.65 \mathrm{kgm} 3$ for mineral soils.

$$
P_{t}=1-\left(\frac{B d}{P d}\right) x 100
$$

Where Bd is bulk density and Pd is particle density.

\section{Aggregate stability}

The indices to be used for aggregate stability determination are mean weight diameter (MWD), dispersion ratio (DR), clay flocculation index (CFI), clay dispersion index (CDI) and aggregate silt + clay (ASC)

The mean weight diameter (MWD) wetting and drying cycles: As an index of macro aggregate stability was determined by the wet sieving method of Kemper \& Rosenau [13]. Soil particles were subjected to three sets of wetting and drying cycles $(3,7$, and 10 cycles). During wetting and drying cycles, soil aggregates were first wetted to field capacity using a micro-misting method, where water was passed through a misting nozzle and delivered as micro-droplets. These micro-droplets form a fog over the soil samples and slowly increase the moisture content of the soil with negligible disruption of the soil aggregates. The wetted samples were allowed to stay for $12 \mathrm{hr}$ at room temperature, then ovendried at $35{ }^{\circ} \mathrm{C}$ for a further period of $12 \mathrm{hr}$. This 24-hr wetting/ drying (W/D) process constituted one W/D cycle. After completion of the wetting and drying cycles, sub-samples were wet-sieved by a method similar to Kemper \& Rosenau [13], using four different sieves of $2,1,0.5$, and $0.25 \mathrm{~mm}$ mesh size.

The dispersion ratio (DR): As described by Mbagwu \& Piccolo [14] was used as an index of micro aggregate stability.

$$
D R=\frac{\% \text { Silt }+ \text { clay in water dispersed samples }}{\% \text { Silt }+ \text { clay in calgon dispersed samples }} \times 100
$$

\section{Clay dispersion index (CDI)}

Clay dispersion index was obtained by dividing the percentage clay obtained without chemical dispersion with percentage clay obtained by chemical dispersion (calgon). It is expressed thus:

$$
C D I=\frac{\% \text { Clay dispersed by water }}{\% \text { clay dispersed in calgon }}
$$

\section{Clay flocculation index (CFI)}

Clay flocculation index (CFI) was calculated by subtracting the total percentage of clay treated with Calgon from the total percentage of clay treated with water and dividing it with total percentage of clay treated with calgon multiplying by 100 this is expressed as:

$$
C F I=\frac{\% \text { clay }(\text { dispersed in calgon })-\text { clay }(\text { dispersed in water })}{\% \text { clay }(\text { dispersed in calgon })} \times 100
$$

\section{Aggregate silt + clay (ASC)}

Aggregate silt clay (ASC) was calculated as: $A S C=\%$ clay + silt $($ calgon $)-\%$ clay + silt $($ water $)$

Saturated hydraulic conductivity (Ksat): Saturated hydraulic conductivity was determined by the constant head method [15].

Organic matter: The organic matter content of the soil sample was determined by Walkely and Black method [16].

Soil pH: Soil pH was determined in 1: 2.5 soil-water suspension ratio [17]. 


\section{Agricultural Research \& Technology: Open Access Journal}

Total nitrogen: Total Nitrogen was done by the Kjeidahl digestion and distillation method as described by Udo et al. [18].

Available phosphorus: Available phosphorus was estimated by the Bray and Kurtz method

\section{Statistical Analysis}

Analysis of variance (ANOVA) for randomized complete block design (RCBD) was used to compare the variations in micro aggregate stability and measured soil chemical properties under the different land use systems and depth. Significantly different means were separated using least significant difference at 5\% level of probability $(\mathrm{p} \leq 0.05)$. Correlation was carried out to show the relationship between studied soil properties

\section{Results and Discussion}

\section{Particle size distribution}

The particle size distribution of the soils studied is shown in Table 1 . At the two depths of $0-15$ and $15-30 \mathrm{~cm}$, the texture of soil under cassava cultivated land (CS) was sandy loam and sandy clay loam was observed at oil palm plantation (OP) and rubber plantation (RP) at 0-15 and 15-3cm depths, respectively. However, oil palm plantation (OP) recorded a clay loam texture at $15-30 \mathrm{~cm}$ depth, while rubber plantation (RP) was observed to have a sandy loam texture at $0-15 \mathrm{~cm}$ depth.

At both depths of $0-15$ and $15-30 \mathrm{~cm}$, respectively, the highest sand contents of 712.7 and $719.3 \mathrm{~g} \mathrm{~kg}^{-1}$ were observed under the cassava cultivated land (CS) while oil palm plantation (OP) had the lowest with values 572.7 and $499.3 \mathrm{~g} \mathrm{~kg}^{-1}$. With regard to the silt contents, oil palm plantation (OP) recorded the highest at the two depths (154.0 and $194.0 \mathrm{~g} \mathrm{~kg}^{-1}$ ) while rubber plantation (RP) recorded the lowest at both depths (100.7 and $127.3 \mathrm{~g} \mathrm{~kg}^{-1}$ ). The highest clay contents were observed under the oil palm plantation (OP) at both depths (273.3 and $306.7 \mathrm{~g} \mathrm{~kg}^{-1}$ ). The lowest clay contents at both depths were observed in cassava cultivated land $\left(146.7 \mathrm{~g} \mathrm{~kg}^{-1}\right)$.

Generally, the sand content increased with depth except oil palm plantation, while the silt and clay contents increased. However, the silt content under cassava cultivated land decreased with depth. As shown in Table 1, and with regards to depth, the particle sizes were significantly $(\mathrm{p} \leq 0.05)$ different. With regards to the land use systems and depths, the sand, silt and clay particles of cassava cultivated land (CS) were significantly $(\mathrm{p} \leq 0.05)$ different from OP and RP. Generally, the sand, silt and clay particles of oil palm plantation (OP) were significantly $(\mathrm{p} \leq 0.05)$ different from CS and RP in both depths.

The high sand contents of the soils could be attributed to the geology of the area. The geology of the area is unconsolidated sand deposits formed over coastal plain sand which are characterized by sandy soils over a wide land area [9]. The continuous destruction of soil structure as well as the deposition of silt-sized particles by runoff water must have led to the decrease in silt content of CS [19].
Table 1: Particle size distribution of soils studied

\begin{tabular}{|c|c|c|c|c|}
\hline \multirow{2}{*}{ Land use } & \multicolumn{4}{|c|}{ Soil Properties } \\
\hline CS & 712.7 & 140.7 & 146.7 & TC \\
\hline OP & 572.7 & 154 & 273.3 & SL \\
\hline RP & 686 & 100.7 & 213.3 & SL \\
\hline Mean & 657.1 & 131.8 & 211.1 & \\
\hline & & $15-30 \mathrm{~cm}$ & & \\
\hline CS & 719.3 & 134 & 146.7 & SL \\
\hline OP & 499.3 & 194 & 306.7 & CL \\
\hline RP & 696 & 127.3 & 286.7 & SCL \\
\hline Mean & 638.2 & 151.8 & 246.7 & \\
\hline LSD & & & & \\
\hline Land Use & 1.02 & 0.97 & 1.57 & \\
\hline Depth & 1.56 & 1.78 & 1.09 & \\
\hline L $\times$ D & 0.86 & 0.65 & 0.04 & \\
\hline
\end{tabular}

CS: Cassava cultivated land; OP: Oil palm plantation; RP: Rubber plantation; $L \times D$ : Interaction of land use $\times$ depth.

The increase in clay with soil depth maybe due to translocation [20], dissolution and leaching of clay materials as a result of intense torrential rainfall, argillation of clay, lessivage and sorting of soil materials [21]. Jaiyeoba [21], observed that increased clay contents at lower depths were due to increase in cultivation. This may be as a result of either increase of clay translocation from the surface to subsurface horizons or removal of clay from the surface by runoff.

\section{Bulk density, total porosity and saturated hydraulic conductivity}

Table 2: Bulk density, total porosity and saturated hydraulic conductivity of soils studied.

\begin{tabular}{|c|c|c|c|}
\hline \multirow[t]{2}{*}{ Land use } & \multicolumn{3}{|c|}{ Soil Properties } \\
\hline & $\mathrm{Bd}\left(\mathrm{Mg} \mathrm{m}^{-3}\right)$ & Pt (\%) & Ksat $\left(\mathrm{cm} \mathrm{min} \mathrm{min}^{-1}\right)$ \\
\hline & & $0-15 \mathrm{~cm}$ & \\
\hline $\mathrm{CS}$ & 1.69 & 36.4 & 0.19 \\
\hline $\mathrm{OP}$ & 1.39 & 47.6 & 0.77 \\
\hline $\mathrm{RP}$ & 1.67 & 37 & 0.22 \\
\hline \multirow[t]{2}{*}{ Mean } & 1.58 & 40.33 & 0.39 \\
\hline & & $15-30 \mathrm{~cm}$ & \\
\hline $\mathrm{CS}$ & 1.9 & 28.3 & 0.12 \\
\hline $\mathrm{OP}$ & 1.62 & 38.77 & 0.46 \\
\hline $\mathrm{RP}$ & 1.85 & 30.27 & 0.2 \\
\hline Mean & 1.72 & 32.45 & 0.26 \\
\hline \multicolumn{4}{|l|}{$\mathrm{LSD}_{0.05}$} \\
\hline Land use & 0.2 & 3.54 & 0.03 \\
\hline Depth & 0.12 & 6.41 & 0.11 \\
\hline $\mathrm{L} \times \mathrm{D}$ & 0.15 & 2.91 & 0.01 \\
\hline
\end{tabular}

CS: Cassava cultivated land; OP: Oil palm plantation; RP: Rubber plantation; L $\times$ D: Interaction of land use $\times$ depth. 
The bulk density, total porosity and saturated hydraulic conductivity of the soils studied are shown in Table 2. At the two depths of $0-15$ and $15-30 \mathrm{~cm}$, cassava cultivated land had the highest bulk density with a value of 1.69 and $1.90 \mathrm{Mg} \mathrm{m}^{-3}$, respectively. The lowest bulk density was observed in oil palm plantation (OP) at the two depths with values ranging from 1.39 to $1.62 \mathrm{Mg} \mathrm{m}^{-3}$. With regard to porosity, OP had the highest at both depths (47.60\% and 38.77\%). Cassava cultivated land (CS) was observed to have the lowest total porosity (36.40\% and $28.30 \%$ ) at both depths. Oil palm plantation had the fastest saturated hydraulic conductivity ranging from 0.46 to $0.77 \mathrm{~cm} \mathrm{~min}^{-1}$ at both depths while cassava cultivated land had the slowest of 0.12 to $0.19 \mathrm{~cm} \mathrm{~min}^{-1}$.

Generally, the bulk density of the soils increased significantly $(p \leq 0.05)$ with depth, whereas total porosity and saturated hydraulic conductivity decreased significantly $(\mathrm{p} \leq 0.05)$ with depth (Table 2). These observations reflected the influence of organic matter on the parameters. With reduced organic matter content, bulk density increased while total porosity decreased resulting to a reduction in saturated hydraulic conductivity [22].

As shown in Table 2, and with reference to the two depths, the values indicated that bulk density, total porosity and saturated hydraulic conductivity were significantly $(p \leq 0.05)$ different. With reference to land use systems in both depths, the bulk density of CS was significantly ( $\mathrm{p} \leq 0.05)$ higher than OP and RP. The porosity under CS were significantly $(\mathrm{p} \leq 0.05)$ different from OP and RP at both depths. The saturated hydraulic conductivity under CS was significantly $(\mathrm{p}<0.05)$ slower than OP and RP at both depths, whereas OP was significantly $(\mathrm{p}<0.05)$ faster than CS and RP.

The variation in bulk density and total porosity may be attributed to the level of organic matter in the soil [23]. The high bulk density, low porosity, slow saturated hydraulic conductivity and infiltration rate observed under CS were similar to the findings of Ahukaemere et al. [24]. He observed consistently higher bulk density in continuously cultivated land than in oil palm plantation. The low bulk density and high porosity with a fast saturated hydraulic conductivity observed under OP may be as a result of the high organic matter content of the OP. This concurred with the findings of Onweremadu \& Mbah [25] who reported that the high level of organic matter in oil palm plantation led to low bulk density, high total volume and favoured transmission of water under saturated conditions. The slow saturated hydraulic conductivity observed under CC may be attributed to the low mean weight diameter, high bulk density and the mechanical disruption of the pore arrangements by tillage [26]. As organic matter decreased from OP to CS, the total porosity reduced. This was consistent with the observations of Oguike et al. [27].

\section{Aggregate stability}

The aggregate stability of soils studied are shown in Table 3. At both depths of $0-15$ and $15-30 \mathrm{~cm}$, OP was observed to have the most stable aggregates at both depths with the highest mean weight diameter (MWD) which ranged from 2.189 to $2.844 \mathrm{~mm}$. cassava cultivated land (CS) was the least aggregated and also showed the greatest tendency to disperse at both depths with the lowest MWD and highest dispersion ratio (DR). The values ranged from 0.768 to $0.825 \mathrm{~mm}$ for MWD and 24.470 to $28.330 \%$ for DR. Oil palm plantation showed the lowest tendency to disperse with the lowest dispersion ratio at both depths. The values ranged from 15.970 to $19.320 \%$. Aggregated silt + clay from the different land use systems were significantly different $(p \leq 0.05)$ at $0-15 \mathrm{~cm}$ depth whereas at the $15-30 \mathrm{~cm}$ depth, soils from CS and RP were statistically similar and less aggregated than soils from OP. The CS and RP soil showed the least resistance to dispersion as revealed by the high CDI and low ASC and CFI values. Also, at $15-30 \mathrm{~cm}$ depth soils from CS and RP were statistically similar with respect to CDI. This may be due to the increase in clay content of soils under the land use systems with depth.

Table 3: Aggregate stability of soils studied.

\begin{tabular}{|c|c|c|c|c|c|}
\hline Land use & \multicolumn{5}{|c|}{ Soil Properties } \\
\hline & MWD (mm) & ASC (\%) & CDI (\%) & CFI (\%) & DR (\%) \\
\hline & & & $0-15 \mathrm{~cm}$ & & \\
\hline CS & 0.768 & 21.8 & 32.05 & 69.2 & 24.47 \\
\hline OP & 2.189 & 24.8 & 20.95 & 79.46 & 15.97 \\
\hline RP & 1.678 & 21.52 & 31 & 68.23 & 17.09 \\
\hline Mean & 1.545 & 22.71 & 28 & 72.3 & 19.177 \\
\hline & & & $15-30 \mathrm{~cm}$ & & \\
\hline CS & 0.825 & 24.79 & 27.1 & 80.14 & 28.33 \\
\hline OP & 2.844 & 31.9 & 18.54 & 82.28 & 19.32 \\
\hline RP & 2.159 & 24.7 & 26.45 & 74.32 & 20.223 \\
\hline Mean & 1.943 & 27.13 & 24.03 & 78.91 & 22.624 \\
\hline LSD & & & & & \\
\hline Land use & 0.284 & 0.1 & 2.17 & 0.95 & 0.651 \\
\hline Depth & 0.214 & 2.01 & 1.02 & 1.43 & 2.001 \\
\hline L $\times$ D & 0.026 & 0.16 & 1.96 & 3.97 & 0.403 \\
\hline
\end{tabular}

CS: Cassava cultivated land; OP: Oil palm plantation; RP: Rubber plantation; $L \times D$ : Interaction of land use $\times$ depth; MWD: Mean weight diameter: ASC: Aggregated silt + clay; CDI: Clay dispersion index; CFI: Clay flocculation index; DR: Dispersion ratio.

Significant variations were also observed in the flocculation abilities of the soils. Clay flocculation at $0^{-1} \mathrm{~cm}$ depth was found to increase in the order RP, CS and OP. This may be as a result of the proportionate increase in clay and silt contents. However, at 15$30 \mathrm{~cm}$ depth, the flocculation ability of soils formed over CS and OP were statistically similar. The exhibition of good structural abilities observed in soils of OP and RP were due to their increased organic matter contents [28] while the reduced aggregation noticed in soil from CS was a result of its reduced OM content [29,30].

At the colloidal level, with regard to 2 depths, the soils formed over OP was the most aggregated and least dispersed as indicated by aggregation (ASC), flocculation (CFI) and dispersion (CDI) indices. Comparatively, soil of CS was the least aggregated at both depths. Sesquioxides and clay mineralogy (not determined) may have played dominant roles in the aggregate stability of the soils. 
The macro aggregation measured with MWD and the dispersion of soils (DR) increased significantly $(\mathrm{p} \leq 0.05)$ with depth. As shown in Table 3 and with regards to depth, the means indicated significant $(\mathrm{p} \leq 0.05)$ differences in both at the macro and micro levels. With reference to land use systems in both depths (Table 3), the MWD of cassava cultivated land (CS) was significantly $(\mathrm{p} \leq 0.05)$ lower than OP and RD. At both depths, mean weight diameter of OP was significantly higher than CS and RP. The MWD of CS was significantly $(\mathrm{p} \leq 0.05)$ different from the other land use systems at both depths. At the macro aggregation level, OP were better than the other land use systems. This observation supported the findings of Celik [26], who reported that mean weight diameter of soil aggregates were significantly greater in oil palm plantation, than in cassava cultivated land and rubber plantation.

Table 4: Effects of wetting/drying cycles on MWD (mm).

\begin{tabular}{|c|c|c|c|c|}
\hline Land use & \multicolumn{4}{|c|}{ Cycles of W/D } \\
\hline & $\mathbf{3}$ & $\mathbf{7}$ & $\mathbf{1 0}$ & LSD $_{\mathbf{0 . 0 5}}$ \\
\hline & & $0-15 \mathrm{~cm}$ & & \\
\hline CS & 0.743 & 0.74 & 0.732 & 0.002 \\
\hline OP & 2.181 & 2.178 & 2.175 & 0.001 \\
\hline RP & 1.66 & 1.652 & 1.649 & 0.001 \\
\hline Mean & 1.528 & 1.523 & 1.519 & \\
\hline & & $15-30 \mathrm{~cm}$ & & \\
\hline CS & 0.813 & 0.809 & 0.8 & 0.003 \\
\hline OP & 2.818 & 2.81 & 2.802 & 0.005 \\
\hline RP & 2.147 & 2.14 & 2.136 & 0.002 \\
\hline Mean & 1.926 & 1.92 & 1.913 & \\
\hline LSD & & & & \\
\hline Land use & 0.1 & 0.112 & 0.004 & \\
\hline Depth & 0.009 & 0.217 & 0.106 & \\
\hline L $\times$ D & 0.012 & 0.02 & 0.016 & \\
\hline
\end{tabular}

CS: Cassava cultivated land; OP: Oil palm plantation; RP: Rubber plantation; $L \times$ D: Interaction of land use $\times$ depth.

The effect of wetting and drying cycle on the mean weight diameter of the soil studied is shown in Table 4. The table showed that the W/D cycle 3 under oil palm plantation had the highest mean weight diameter $(2.181$ and $2.811 \mathrm{~mm})$ at both depths, while W/D cycle 10 under cassava cultivated land recorded the lowest $(0.732$ and $0.800 \mathrm{~mm})$ at both depths. Generally, the mean weight diameter of the soils increased significantly $(\mathrm{p} \leq 0.05)$ with depth after the wetting and drying cycle. As shown in Table 4, and with reference to the two depths, the values indicated that mean weight diameter were significantly $(\mathrm{p} \leq 0.05)$ different. With reference to land use systems in both depths, mean weight diameter of CS was significantly $(\mathrm{p} \leq 0.05)$ lower than OP and RP after the wetting and drying cycle. However, with respect to the wetting and drying cycles, the mean weight diameter under W/D cycle 3 was significantly $(\mathrm{p} \leq 0.05)$ higher than other cycles.

The low MWD observed in CS may be attributed to tillage with traditional implements and clean weeding, together with reduced organic matter [31]. Cultivation break up soil aggregates and expose previously inaccessible organic matter to microbial attack and accelerates decomposition and mineralization of organic matter [32]. The high value of MWD observed under OP may be attributed to the high organic matter contents of the soils (Table 4). This may be associated with increase in the percentage of binding materials (polysaccharides, humic and humin) contained in the organic materials which enable soil particles to aggregate with each other $[33,34]$. The higher DR observed in CS may be attributed to the colloidal nature of clay which could promote the poor aggregation in the soils [35].

\section{Organic matter, available phosphorus, total nitrogen and $\mathrm{pH}$ of soils studied}

Table 5: Organic matter available phosphorus, total nitrogen and $\mathrm{pH}$ of soils studied.

\begin{tabular}{|c|c|c|c|c|}
\hline \multirow[t]{2}{*}{ Land Use } & \multicolumn{4}{|c|}{ Soil Properties } \\
\hline & OM $\left(\mathrm{g} \mathrm{kg}^{-1}\right)$ & Aval. P (Mg Kg $\left.{ }^{-1}\right)$ & Total N (\%) & pH \\
\hline & & & $0-15 \mathrm{~cm}$ & \\
\hline CS & 25.9 & 23.667 & 0.139 & 5.633 \\
\hline $\mathrm{OP}$ & 28.3 & 21 & 0.17 & 5.933 \\
\hline $\mathrm{RP}$ & 26.6 & 20.133 & 0.158 & 6.067 \\
\hline \multirow[t]{2}{*}{ Mean } & 26.93 & 21.6 & 0.156 & 5.878 \\
\hline & & & $15-30 \mathrm{~cm}$ & \\
\hline CS & 21.7 & 15.7 & 0.116 & 4.8 \\
\hline OP & 24 & 13.833 & 0.129 & 5.167 \\
\hline RP & 23.4 & 14.667 & 0.12 & 5.5 \\
\hline Mean & 23.03 & 14.733 & 0.122 & 5.156 \\
\hline \multicolumn{5}{|l|}{$\mathrm{LSD}_{0.05}$} \\
\hline $\begin{array}{c}\text { Land use } \\
0.091\end{array}$ & & 0.811 & 0.003 & 0.016 \\
\hline Depth & 0.158 & 1.26 & 0.021 & 0.48 \\
\hline $\mathrm{L} \times \mathrm{D}$ & 0.07 & 0.521 & 0.004 & 0.011 \\
\hline
\end{tabular}

CS: Cassava cultivated land; OP: Oil palm plantation; RP: Rubber plantation; L $\times$ D: Interaction of land use $\times$ depth.

The organic matter, available phosphorus, total nitrogen and $\mathrm{pH}$ of the soils studied are shown in Table 5. At both depths of 0-15 and $15-30 \mathrm{~cm}$, oil palm plantation (OP) was observed to have the highest organic matter at both depths with values 28.300 and $24.000 \mathrm{~g} \mathrm{~kg}^{-1}$, respectively. The cassava cultivated land (CS) was observed to have the lowest organic matter at both depths with values 25.900 and $23.400 \mathrm{~g} \mathrm{~kg}^{-1}$. Under available phosphorus, CS recorded the highest at both depths with values 23.667 and $15.700 \mathrm{Mg} \mathrm{Kg}^{-1}$, while oil palm plantation (OP) was observed to have the lowest available phosphorus (21.000 and $13.833 \mathrm{Mg} \mathrm{Kg}^{-1}$ ) at both depths. At the depths of $0-15 \mathrm{~cm}$ and $15-30 \mathrm{~cm}$, OP recorded the highest total nitrogen $(0.170$ and $0.129 \%)$ while CS recorded the lowest total nitrogen ( 0.139 and $0.116 \%)$. With regards to $\mathrm{pH}$ at both depths, rubber plantation (RP) had the highest $\mathrm{pH}$ values ranging from 5.500 to 6.067 , while cassava cultivated land (CS) was observed to have the lowest $\mathrm{pH}$ values ranging from 4.800 to 5.633. With respect to both depths, cassava cultivated land (CS) was very low in organic matter with a strongly acidic reaction 
whereas rubber plantation (RP) was high in organic matter with a slightly acidic soil reaction [36]. However, the soil studied under oil palm plantation (OP), was high in organic matter having a moderate acidic soil reaction [36].

As shown in Table 5 and referring to depth, the means indicated significant $(\mathrm{p} \leq 0.05)$ decrease in organic matter, available phosphorus, total nitrogen and $\mathrm{pH}$. With respect to land use systems in both depths, the organic matter, total nitrogen and $\mathrm{pH}$ of cassava cultivated land were significantly $(p \leq 0.05)$ lower than the other land use systems. The decrease in organic matter content with soil depth may be attributed to the continuous accumulation of undecayed and partially decomposed plant and animal residues on the surface soil [37]. The high organic matter observed under OP and RP may be attributed to the presence of litter falls and roots [38]. The low organic matter observed in cassava cultivated land may be attributed to the effects of continuous cultivation that aggravates organic matter oxidation [38-40].

The decrease in $\mathrm{pH}$ with increase in soil depth may be as a result of larger organic matter content observed at the top soils which helped to bind tightly with aluminium ions and reduce their activity in the soil solution which thereby raise soil $\mathrm{pH}$ and reduce acidity [37]. The decrease of soil $\mathrm{pH}$ with depth might also be attributed to the increase in clay contents with depth which have the tendency to furnish hydrogen ions from clay colloidal surface to the solution thereby reducing soil $\mathrm{pH}$. The slightly acidic and moderately acidic nature of the soil under OP and RP could be attributed to the high exchangeable bases [38].

\section{Correlation matrix of the soil properties studied}

The correlation of soil properties studied under cassava cultivated land is shown in Table 6. The Table showed that aggregate stability was strongly correlated with clay contents, bulk density, total porosity, ASC, CFI and organic matter. The macro aggregation measured with mean weight diameter (MWD) positively, correlated, significantly with clay content ( $r=0.643$ ), ASC $(\mathrm{r}=0.759)$, CFI ( $\mathrm{r}=0.611)$ and organic matter $(\mathrm{r}=0.853)$. Dispersion ratio was observed to have a positive, significant, correlation with bulk density ( $\mathrm{r}=0.629)$ and a negative, significant, correlation with total porosity ( $\mathrm{r}=-0.631)$, ASC $(\mathrm{r}=-0.861)$ and CFI $(\mathrm{r}=-0.500)$. The indication was that mean weight diameter increased as clay contents, organic matter, ASC and CFI increased, resulting to better aggregation of the soil. However, dispersion ratio increased as bulk density increased with a corresponding decrease in total porosity, ASC and CFI.

Table 6: Correlation matrix of soil properties under CS.

\begin{tabular}{|c|c|c|c|c|c|c|c|c|c|c|c|c|}
\hline & $\begin{array}{l}\text { SAND } \\
\left(\text { (gkg }^{-1}\right)\end{array}$ & $\begin{array}{c}\text { SILT } \\
\left(\text { gkg }^{-1}\right)\end{array}$ & $\begin{array}{c}\text { CLAY } \\
\left(\text { (gkg }^{-1}\right)\end{array}$ & $\begin{array}{c}\text { Bd (Mg } \\
\left.\text { m }^{-3}\right)\end{array}$ & Pt (\%) & $\begin{array}{c}\text { Ksat } \\
\left(\text { cmmin }^{-1}\right)\end{array}$ & $\begin{array}{l}\text { MWD } \\
(\mathrm{mm})\end{array}$ & $\begin{array}{l}\text { DR } \\
(\%)\end{array}$ & $\begin{array}{l}\text { ASC } \\
(\%)\end{array}$ & $\begin{array}{l}\text { CDI } \\
(\%)\end{array}$ & $\begin{array}{l}\text { CFI } \\
(\%)\end{array}$ & $\underset{\left(\mathrm{gkg}^{-1}\right)}{\mathrm{OM}}$ \\
\hline SAND $\left(\mathrm{gk} \mathrm{g}^{-1}\right)$ & - & & & & & & & & & & & \\
\hline SILT $\left(\mathrm{gkg}^{-1}\right)$ & $-0.911^{* *}$ & - & & & & & & & & & & \\
\hline CLAY $\left(\mathrm{gkg}^{-1}\right)$ & -0.304 & -0.107 & - & & & & & & & & & \\
\hline $\mathrm{Bd}\left(\mathrm{Mg} \mathrm{m}^{-3}\right)$ & -0.261 & 0.386 & -0.264 & - & & & & & & & & \\
\hline Pt (\%) & 0.273 & -0.4 & 0.26 & $-0.999^{* *}$ & - & & & & & & & \\
\hline Ksat $\left(\mathrm{cmmin}^{-1}\right)$ & $-0.774^{*}$ & $0.817^{* *}$ & -0.022 & -0.015 & 0.001 & - & & & & & & \\
\hline MWD (mm) & -0.341 & 0.079 & $0.643^{*}$ & 0.426 & -0.43 & 0.081 & - & & & & & \\
\hline DR (\%) & -0.036 & 0.09 & -0.131 & $0.629^{*}$ & $-0.631^{* *}$ & -0.198 & 0.382 & - & & & & \\
\hline ASC (\%) & 0.313 & -0.216 & -0.251 & $-0.732 *$ & $0.736^{* *}$ & 0.077 & $0.759^{*}$ & $-0.861^{*}$ & - & & & \\
\hline CDI (\%) & -0.081 & 0.029 & 0.149 & $-0.789 * *$ & $0.782^{* *}$ & 0.212 & -0.473 & -0.226 & 0.434 & - & & \\
\hline CFI (\%) & -0.012 & -0.073 & 0.192 & $-0.764^{*}$ & $0.763^{*}$ & -0.041 & $0.611^{* *}$ & $-0.500^{*}$ & $0.614^{* *}$ & $0.838^{* *}$ & - & \\
\hline $\mathrm{OM}\left(\mathrm{gkg}^{-1}\right)$ & -0.04 & 0.001 & 0.093 & $-0.690^{* *}$ & $0.682^{*}$ & 0.321 & $0.853^{* *}$ & -0.008 & 0.246 & $0.889 *$ & $0.506^{*}$ & - \\
\hline
\end{tabular}

** Correlation is significant at the 0.01 level.

* Correlation is significant at the 0.05 level

Table 7 revealed that aggregate stability strongly correlated with sand, silt, clay, organic matter, ASC and CFI under the oil palm plantation. Under this land use, MWD negatively correlated significantly with sand ( $\mathrm{r}=-0.74)$ and positively correlated significantly with clay $(r=0.95)$ and organic matter $(r=0.95)$. The indication was that mean weight diameter increased as sand decreased with an increase in clay content and organic matter increased. Dispersion ratio representing micro aggregation negatively, correlated with sand $(\mathrm{r}=-0.61)$, ASC $(\mathrm{r}=-0.68)$, total porosity $(\mathrm{r}=-0.50)$ and $\mathrm{CFI}(\mathrm{r}=-0.71)$. This indicated that increase in sand particles, ASC, total porosity and CFI decreased the soil micro aggregation.
The correlation of soil properties studied under rubber plantation is shown in Table 8. The Table showed that aggregate stability was strongly correlated with particle size, bulk density, total porosity and organic matter. The macro aggregation measured with mean weight diameter (MWD) positively, correlated, significantly with clay content $(\mathrm{r}=0.872)$, total porosity $(\mathrm{r}=0.828)$ and organic matter $(\mathrm{r}=0.841)$. Mean weight diameter negatively, correlated, significantly with sand content $(\mathrm{r}=-0.509)$, silt content $(\mathrm{r}=-0.565)$, bulk density ( $\mathrm{r}=-0.806)$ and CDI $(\mathrm{r}=-0.526)$. Dispersion ratio was observed to have a positive, significant, correlation with sand content $(\mathrm{r}=0.556)$, silt content $(\mathrm{r}=0.531)$, bulk density $(r=0.873)$ and a negative, significant, correlation with clay content 
$(\mathrm{r}=-0.825)$, total porosity $(\mathrm{r}=-0.874)$, mean weight diameter $(\mathrm{r}=-$ $0.976)$ and organic matter ( $\mathrm{r}=-0.858)$. The indication was that mean weight diameter increased as clay contents, organic matter and total porosity increased, resulting to better aggregation of the Table 7: Correlation matrix of soil properties under OP. soil. However, dispersion ratio increased as sand and silt contents and bulk density increased with a corresponding decrease in clay content, total porosity and organic matter content.

\begin{tabular}{|c|c|c|c|c|c|c|c|c|c|c|c|c|}
\hline & $\begin{array}{l}\text { SAND } \\
\text { (g/kg) }\end{array}$ & $\begin{array}{l}\text { SILT (g/ } \\
\text { kg) }\end{array}$ & $\begin{array}{l}\text { CLAY } \\
\text { (g/kg) }\end{array}$ & $\begin{array}{c}\text { Bd (Mg } \\
\left.\mathbf{m}^{-3}\right)\end{array}$ & Pt (\%) & $\begin{array}{c}\text { Ksat } \\
\left(\mathrm{cmmin}^{-1}\right)\end{array}$ & $\begin{array}{l}\text { MWD } \\
(\mathrm{mm})\end{array}$ & DR (\%) & $\operatorname{ASC}(\%)$ & CDI (\%) & CFI (\%) & $\begin{array}{c}\text { OM } \\
\left(\mathrm{gkg}^{-1}\right)\end{array}$ \\
\hline $\begin{array}{l}\text { SAND } \\
\left(\mathrm{gkg}^{-1}\right)\end{array}$ & - & & & & & & & & & & & \\
\hline SILT $\left(\mathrm{gkg}^{-1}\right)$ & $-0.89 * *$ & - & & & & & & & & & & \\
\hline CLAY gkg $^{-1}$ ) & $-0.88^{* *}$ & $0.59^{*}$ & - & & & & & & & & & \\
\hline $\begin{array}{c}\mathrm{Bd}(\mathrm{Mg} \\
\left.\mathrm{m}^{-3}\right)\end{array}$ & $0.65^{*}$ & $-0.83^{* *}$ & -0.32 & - & & & & & & & & \\
\hline Pt (\%) & $-0.64^{* *}$ & $0.83^{* *}$ & 0.32 & $-0.99 * *$ & - & & & & & & & \\
\hline $\begin{array}{c}\text { Ksat } \\
\left(\mathrm{cmmin}^{-1}\right)\end{array}$ & 0.45 & $-0.66^{*}$ & -0.14 & 0.42 & -0.43 & - & & & & & & \\
\hline $\begin{array}{l}\text { MWD } \\
(\mathrm{mm})\end{array}$ & $-0.74^{*}$ & 0.39 & $0.95^{* *}$ & -0.05 & 0.05 & 0.05 & - & & & & & \\
\hline DR (\%) & $-0.61 * *$ & $0.65^{* *}$ & 0.42 & -0.5 & $-0.50^{*}$ & -0.04 & 0.38 & - & & & & \\
\hline ASC (\%) & 0.3 & -0.38 & -0.14 & 0.02 & -0.01 & 0.13 & -0.28 & $-0.68^{* *}$ & - & & & \\
\hline CDI (\%) & 0.33 & $-0.58^{*}$ & -0.07 & 0.33 & -0.33 & 0.3 & -0.13 & -0.4 & $0.78^{*}$ & - & & \\
\hline CFI (\%) & 0.47 & $-0.52^{*}$ & -0.32 & 0.23 & -0.23 & 0.09 & -0.44 & $-0.71^{*}$ & $0.94^{* *}$ & $0.87^{* *}$ & - & \\
\hline $\mathrm{OM}\left(\mathrm{gkg}^{-1}\right)$ & -0.01 & -0.33 & 0.37 & 0.17 & -0.18 & 0.41 & $0.95^{* *}$ & -0.34 & $0.75^{* *}$ & $0.82^{*}$ & $0.68^{*}$ & - \\
\hline
\end{tabular}

** Correlation is significant at the 0.01 level.

* Correlation is significant at the 0.05 level.

The influence of clay on soil aggregate stability maybe attributed to its ability to form slurry when in contact with moisture. Zhang \& Horn [41] who made similar observation reported that clay content of soils determined to a large extent, the aggregate stability of the soil. The positive relationship between organic matter and mean weight diameter may be attributed to

the prevalence of binding materials (polysaccharides, humic and humin) available in organic materials enabling soil particles to aggregate with each other [34]. This corroborated with the findings of Beata et al. [42], who reported that as clay content and organic matter increased, the soil became more structurally aggregated [43-50].

Table 8: Correlation matrix of soil properties under RP.

\begin{tabular}{|c|c|c|c|c|c|c|c|c|c|c|c|c|}
\hline & $\begin{array}{l}\text { SAND } \\
\left(\mathrm{gkg}^{-1}\right)\end{array}$ & $\begin{array}{c}\text { SILT } \\
\left(\mathrm{gkg}^{-1}\right)\end{array}$ & $\begin{array}{c}\text { CLAY } \\
\left(\mathrm{gkg}^{-1}\right)\end{array}$ & $\begin{array}{c}\mathrm{Bd}(\mathrm{Mg} \\
\left.\mathrm{m}^{-3}\right)\end{array}$ & Pt (\%) & $\begin{array}{c}\text { Ksat } \\
\left(\text { cmmin }^{-1}\right)\end{array}$ & $\begin{array}{l}\text { MWD } \\
\text { (mm) }\end{array}$ & $\begin{array}{l}\text { DR } \\
\text { (\%) }\end{array}$ & $\begin{array}{l}\text { ASC } \\
\text { (\%) }\end{array}$ & $\begin{array}{l}\text { CDI } \\
\text { (\%) }\end{array}$ & CFI (\%) & $\underset{\left(\mathrm{gkg}^{-1}\right)}{\mathrm{OM}}$ \\
\hline SAND $\left(\mathrm{gkg}^{-1}\right)$ & - & & & & & & & & & & & \\
\hline SILT $\left(\mathrm{gkg}^{-1}\right)$ & -0.278 & - & & & & & & & & & & \\
\hline $\operatorname{CLAY}\left(\mathrm{gkg}^{-1}\right)$ & $-0.652^{*}$ & -0.131 & - & & & & & & & & & \\
\hline $\mathrm{Bd}\left(\mathrm{Mg} \mathrm{m}^{-3}\right)$ & $-0.779 * *$ & -0.211 & $0.759^{* *}$ & - & & & & & & & & \\
\hline Pt (\%) & $0.776^{* *}$ & 0.216 & $-0.758^{*}$ & $-0.999 * *$ & - & & & & & & & \\
\hline $\begin{array}{c}\text { Ksat } \\
\left(\mathrm{cmmin}^{-1}\right)\end{array}$ & 0.487 & -0.205 & $-0.660^{* *}$ & -0.306 & 0.303 & - & & & & & & \\
\hline MWD (mm) & $-0.509 *$ & $-0.565^{*}$ & $0.872^{*}$ & $-0.806^{*}$ & $0.828^{* *}$ & -0.377 & - & & & & & \\
\hline DR (\%) & $0.556^{* *}$ & $0.531^{*}$ & $-0.825^{* *}$ & $0.873^{* *}$ & $-0.874^{* *}$ & 0.228 & $-0.976^{* *}$ & - & & & & \\
\hline ASC (\%) & $0.914^{* *}$ & $-0.464^{* *}$ & $-0.669 *$ & $-0.728^{*}$ & $0.726^{* *}$ & $0.626^{* *}$ & -0.391 & 0.421 & - & & & \\
\hline CDI (\%) & $0.928^{*}$ & -0.251 & $-0.721^{*}$ & $-0.689 *$ & $0.686^{*}$ & $0.769^{* *}$ & $-0.526^{*}$ & 0.494 & $0.905^{* *}$ & - & & \\
\hline CFI (\%) & $0.952^{*}$ & -0.267 & $-0.601^{* *}$ & $-0.664^{* *}$ & $0.663^{* *}$ & 0.351 & -0.484 & 0.539 & $0.787^{* *}$ & $0.833^{*}$ & - & \\
\hline $\mathrm{OM}\left(\mathrm{gkg}^{-1}\right)$ & $0.861^{* *}$ & 0.078 & $-0.897^{* *}$ & $-0.852^{* *}$ & $0.851^{* *}$ & 0.471 & $0.841^{* *}$ & $-0.858^{*}$ & $0.743^{*}$ & $0.808^{*}$ & $0.865^{* *}$ & - \\
\hline
\end{tabular}

${ }^{* *}$ Correlation is significant at the 0.01 level.

* Correlation is significant at the 0.05 level.

Conclusion

Soils of different land use systems; cassava cultivated land (CS), oil palm plantation (OP), and rubber plantation (RP) were studied at Ikpe Ikot Nkon, Ini Local Government Area in Akwa Ibom State. The principal objective was to compare the impact of each land use system on the aggregate stability and selected 
chemical properties of the soil. The relationship between selected soil properties and the aggregate stability was also determined in the study. The results of the selected properties under study showed that the soil properties varied with different land use systems. The particle size distribution recorded that sand-sized particles dominated other fractions. In cassava cultivated land and rubber plantation $(15-30 \mathrm{~cm})$, the textural class was sandy loam (SL), while other land use systems were dominated by sandy clay loam (SCL) and clay loam (CL). Porosity varied with bulk density in the land use systems. High total porosity and low bulk density were observed in oil palm plantation (OP), while cassava cultivated land (CS) had high bulk density and low total porosity. Saturated hydraulic conductivity of the soils varied across the land use systems with organic matter playing an important role in the soil moisture conduction against a hydraulic gradient. Soils under oil palm were more structurally aggregated than others. Dispersion ratio of soils was high in cassava cultivated land (CS) which showed that the soils are highly erodible. The $\mathrm{pH}$ of the soils studied ranged from very strongly acidic to moderately acidic. Organic matter was generally low in cassava cultivated land (CS) but high in oil palm plantation (OP). Soils under from OP and RP exhibited higher structural development and better OM contents than the soils under CS. Therefore, management practices such as heavy OM application to stabilize soils under CS against erosion and other mechanical manipulations should be encouraged. This will enhance sustainable utilization of such soils.

\section{References}

1. Barthe B, Roose E (2002) Aggregate stability as an indicator of soil susceptibility to runoff and erosion; validation at several levels. Catena 47(2): 133-149.

2. Diaz-Zorita M, Perfect E, Grove JH (2002) Disruptive methods for assessing soil structure. Soil and Tillage Research 64(1-2): 3-22.

3. Jastrow JD (1996) Soil aggregate formation and the accrual of particulate and mineral-associated organic matter. Soil Biol Biochem 28(4-5): 665-676.

4. Tisdall JM, Oades JM (1982) Organic matter and water-stable aggregates. J Soil Sci 33(2): 141-163.

5. Cosentino D, Chenu C, Le Bissonnais Y (2006) Aggregate stability and microbial community dynamics under drying-wetting cycles in a silt loam soil. Soil Biology and Biochemistry 38(8): 2053-2062.

6. Shepherd MA, Harrison R, Webb J (2002) Managing soil organic matter - implications for soil structure on organic farms. Soil Use and Management 18(1): 284-292.

7. Oguike PC, Onwuka BM (2017) Variations in Texture, Water Retention and Transmission, Organic Matter and $\mathrm{pH}$ of Soils under Selected Land Use Systems at Ubakala Umuahia, South-Eastern Nigeria. Journal of Scientific and Engineering Research 4(7): 147-155.

8. Lambin EF, Geist H (2006) Land use and land cover change. Local processes and global impact. Environmental Sciences Nature Conservation \& Biodiversity, Springer, Germany, pp. 77-113.

9. Ogban PI, Obi JC (2010) The relation between natural fallow and soil quality in Akwa Ibom state, southeastern Nigeria. Nigerian journal of agriculture, food and environment 6(3): 34-43.

10. Nigeria Meteorological Agency (2015) Seasonal rainfall prediction for 2015. Nigeria meteorological publications. Maitana, FCT Abuja.
11. Kettler TA, Airan JW, Gilbert TL (2001) Simplified method for soil particle size determination to accompany soil quality analysis. Publications from USDA-ARS/UNL faculty. Paper 305.

12. Blake GR (2003) Bulk density in methods of soil analysis part 1 physical and mineralogical properties. pp. 374-390.

13. Kemper WD, Rosenau RC (1986) Size distribution of aggregates in methods of soil analysis. In: Klute A (Edt.), part 1. ( $2^{\text {nd }}$ Edn). Agron monogr 9: 425-442.

14. Mbagwu JSC, Piccolo A (1990) Some physical properties of structural aggregator separated from organic waste-amended soil. Biological waste 33(2): 257-269.

15. Stolte J (1997) Manual of soil physical measurement version 3, Wageningen D.L.O Starring centre, Tech Doc 37: 77.

16. Nelson DW, Summers LE (1982) Total carbon and organic matter in methods of soil analysis part II. In: Page AL (Eds.), Chemical and microbiological properties. Am Soc Agron Maidson WI 359-580.

17. Mclean EO (1982) Soil pH and lime requirement. In: Pager AL (Edt.), Method of soil analysis II, second edition. Argon- monology Maidison, WL. ASA and SSA 9: 199 -224.

18. Udo EJ, Ibia TO, Ogunwale JA, Ano AA, Esu IE (2009) Manual of Soil, Plant and Water Analyses. Published by Sibon Books Limited, Lagos Nigeria, p. 31-33.

19. Ufot UO, Iren OB, Chikere Njoku CU (2016) Effects of land use on soil physical and chemical properties in Akokwa area of Imo state. Nigeria. Int J life Sci Scienti Res 2(3): 273-278.

20. Agoume V, Birang AM (2009) Impact of land use systems on some physical and chemical soil properties of an oxisol in the humid forest zone of Southern Cameroon. Tropicultura 27(1): 15-20.

21. Ojanuga AG (2003) Soil survey. Classification and land use. Proceedings of the $28^{\text {th }}$ annual conference of the soil science society of Nigeria, NRCRI, Umudike Nigeria, pp. 285-297.

22. Banuhardt RL, Lascano KJ (1996) Rain infiltration as affected by wheat residue amount and distribution in ridget tillage. Soil Sci SOC Am J 60(6): 1908-1913.

23. Okolo CC, Nwite JN, Ezeaku PE, Eke NC, Ezeudo VC, et al. (2013) Assessment of Selected Physiochemical Properties of Soils for Site Suitable for Waste Disposal in Abakaliki, South East, Nigeria. Journal of Resources Development and Management 1: 26-29.

24. Ahukaemere CM, Ndukwu BN, Agim LC (2012) Soil quality and soil degradation as influenced by agricultural land use types in the humid environment. International Journal of forest, soil and erosion 2(4): 23-28.

25. Onweremadu EU, Mbah CN (2009) Changes in Epipedal Development in Soils of a Graverly Hilly Terrain. Report and Opinion 1(2): 1-11.

26. Celik I (2005) Land use effect on organic matter and physical properties of soil in a Southern Mediterranean highland of turkey. Soil and Tillage Research 83(2): 270-277.

27. Oguike PC, Chukwu GO, Njoku NC (2006) Physio-chemical properties of a haplic Acrisol in South Eastern Nigeria amended with rice waste and NPK fertilizer. African J Biotechnol 5(11): 1058-1061.

28. Igwe CA (2011) Tropical soils; physical properties: In: Glinski J, Hovabik J, Lipiec J (Eds.), Encyclopedia of Agrophysics ( $\left.1^{\text {st }} e d n\right)$, Springer pp. 934-937.

29. Onunkwo AA, Obioha YE, Oha IA (2013) Structural and land cover mapping of Ohafia area, south eastern Nigeria. Using remote sensing technique. Intl J of Engineering trends and development 3(6): 1-8.

30. Myravarapu R, Mitchel CC, Savoy HJ (2014) Soils of the south eastern US: In soil test methods from the southeastern United State. Southern Cooperative Series Bulletin. No. 419. 
31. Oguike PC, Mbagwu JSC (2009) Variations in some physical properties and organic matter content of soils of coastal plain sand under different land use types. World Journal of Agricultural Science 5(1): 63-69.

32. Shepherd TG, Newman RH, Ross CW, Dando JL (2001) Tillage induced changes in soil structure and soil organic matter fractions. Aust J Soil Res 39(3): 465-489.

33. Eneje RC, Lemoha K (2012) Heavy metal content and physio chemical properties of municipal solid waste dump soil in Owerri, Imo State. Int J of Modern Eng Res 2(5): 3795-3799.

34. Turgut B, Kose B (2015) Improvements in aggregate stability of recently deposited sediments supplemented with tea waste and farmyard manure. Soil earth discuss 7: 2037-2053.

35. Ghezzi JL (2010) Influence of clay mineralogy on soil dispersion behavior and water quality. California polytechnic state university, USA, pp. 46-57.

36. Brady, Weil (2002) Nature and Properties (13 ${ }^{\text {th }}$ edn), Pearson Hall Inc and Dowling Kindersely. UK, pp. 122.

37. Nega E, Heluf G (2013) Effect of land use changes and soil depth on soil organic matter, TN and available phosphorus, contents of soils in senbat water shed, western Ethiopia. ARPN Journal of Agricultural and Biological Science 8(3): 206-212.

38. Alemayeha K, Sheleme B (2013) Effects of different land use systems on selected soil properties in South Ethiopia. Journal of Soil Science and Environmental Management 4(5): 100-107.

39. Wakene N (2011) Assessment of important physiochemical properties of soils under different management systems in Boko area, Western Ethiopia. Alemaya Ethiopia, p. 109.

40. Malo DD, Schumacher TE, Doolittle JJ (2003) Long-term cultivation impacts on selected soil properties in the Northern Great Plains. Soil Tillage Res 81(2): 277-291.

41. Zhang B, Horn R, Zhao QG, Baumgarhi T (2001) Shear strength of surface soil as affected by bulk density and soil water content. Soil Tillage Research 59(3-4) 97-106.

42. Beata H, Hammerova A, Jandak J, Simeckova J, Vlcek V (2014) Soil aggregate stability and soil organic matter on chernozems of South Moravia. Mendelnet, pp. 260-265.

43. Ayu IW, Sugeng Prijono, Soemarno (2013) Assessment of infiltration rate under different dry land types in Illerlives sub district, Sumbuwa Bester, Indonesia. Journal of natural science research 3(10): 71-76.

44. Igwe CA (2005) Soil physical properties under different management systems and organic matter effects on soil moisture along catena in South eastern Nigeria. Tropical and Sub-Tropical Agro Ecosystem 5(2): 57-66.

45. Jaiyoba IA (2003) Changes in soil properties due to continuous cultivation in Nigeria semi-arid savannah. Soil tillage and research 70(1): 91-98.

46. Malagwi WB, Abu ST (2011) Variation in some physical properties of soils formed on a hilly terrain under different land use types in Nigerian Savannah. Int Journal of Sciences 6(3): 150-163.

47. Neris J, Jimenez C, Fuentes J, Morillas G, Tejedor M (2012) Vegetation and land use effect in soil properties and water infiltration of 'andisols in Tenerife (Canary Island, Spain). Catena 98: 55-62.

48. Ojanuga AG (2003) Soil survey. Classification and land use. Proceedings of the $28^{\text {th }}$ annual conference of the soil science society of Nigeria, NRCRI, Umudike Nigeria, pp. 285-297.

49. Onweremadu EU, Ndukwu BN, Ohiri KU, Ihem EE, Osuji GE, et al. (2009) Variability in particle-size distribution of soils as affected by crude oil spillage. International journal of soil science 1(1): 104-109.

50. Youngs EG (2001) Hydraulic conductivity of saturated soils. In: Soil and Environmental Analysis. In: Smith KA, Mullins CE, (Eds.), Physical Methods. ( $2^{\text {nd }}$ edn), Marcel Decker Inc. New York, USA, p: 637.

Your next submission with Juniper Publishers
will reach you the below assets
- Quality Editorial service
- Swift Peer Review
- Reprints availability
- E-prints Service
- Manuscript Podcast for convenient understanding
- Global attainment for your research
- Manuscript accessibility in different formats
( Pdf, E-pub, Full Text, Audio)
- Unceasing customer service
Track the below URL for one-step submission
https://juniperpublishers.com/online-submission.php

